\title{
Supplemental fermented plant product ('Manda Koso') reduces succinate and deoxycholate, as well as elevates IgA and mucin levels, in rats fed a high-fat diet
}

\author{
YONGSHOU YANG ${ }^{1}$, NOVITA VIVI SITANGGANG ${ }^{1}$, YUKAKO OKAZAKI ${ }^{2}$, HIROYUKI TOMOTAKE ${ }^{3}$, \\ KENTARO ARITA ${ }^{4}$, TAKAYUKI ASHIDA ${ }^{4}$ and NORIHISA KATO ${ }^{1}$ \\ ${ }^{1}$ Graduate School of Biosphere Science, Hiroshima University, Higashi-Hiroshima, Hiroshima 739-8528; \\ ${ }^{2}$ Faculty of Human Life Sciences, Fuji Women's University, Ishikari 061-3204; ${ }^{3}$ Iida Women's Junior College, \\ Iida 395-0812; ${ }^{4}$ Manda Fermentation Co., Ltd., Onomichi, Hiroshima 722-2192, Japan
}

Received June 25, 2015; Accepted July 15, 2015

DOI: $10.3892 /$ br.2015.506

\begin{abstract}
Manda Koso' is a commercial fermented plant product (FPP) made from 53 types of fruits and vegetables that have been fermented for $>3$ years and 3 months. We hypothesized that FPP intake improves the luminal environment of rats fed a high-fat diet. Thus, the present study examined the effects of consumption of 5\% FPP diet for 3 weeks on colonic luminal parameters in rats fed a $30 \%$ beef tallow diet. Food intake and body weight gain were unaffected. Consumption of the FPP diet did not influence the proportions of Bifidobacterium, Lactobacillus, Bacteroides, Prevotella or Clostridium in cecal contents. However, the FPP diet caused a significant reduction (-88\%) in the level of cecal succinate, a putative inflammatory signal $(\mathrm{P}<0.01)$, but did not affect the levels of $n$-butyrate, propionate, acetate and lactate. The fecal levels of deoxycholate and hyodeoxycholate, which are toxic bile acids, were also significantly reduced by the FPP diet $(\mathrm{P}<0.05)$. The FPP diet significantly increased fecal immunoglobulin A and mucins responsible for intestinal immune and barrier functions $(\mathrm{P}<0.05)$. The results suggest that the consumption of FPP is beneficial for the colonic luminal environment in rats fed a high-fat diet.
\end{abstract}

\section{Introduction}

'Manda Koso' (Manda Fermentation Co., Ltd., Onomichi, Japan) is a fermented plant product (FPP) made of naturally fermented fruits, plant roots, cereals, marine algae and kokuto,

Correspondence to: Professor Norihisa Kato, Graduate School of Biosphere Science, Hiroshima University, 1-4-4 Kagamiyama, Higashi-Hiroshima, Hiroshima 739-8528, Japan

E-mail: nkato@hiroshima-u.ac.jp

Abbreviations: FPP, fermented plant product

Key words: fermented plant product, succinate, mucins, deoxycholate, immunoglobulin A a type of non-antifungal cane sugar. The raw ingredients are crushed and fermented by Lactobacillus and yeast generated spontaneously from raw materials at room temperature for 3 years and 3 months. The product is a well-known natural health food that is consumed in Japan. The FPP is a sweet, black-brown, paste-like substance comprising 36.9\% water, $2.4 \%$ proteins and amino acids, $3.7 \%$ dietary fibers, $55.2 \%$ carbohydrates and $1.8 \%$ ash. The consumption of FPP is reported to reduce the fat content without affecting bone weight or strength in ovariectomized rats (1). The FPP also exhibits free radical scavenging activity (2). The consumption of FFP in fish decreases thiobarbituric-acid reactive substance levels in their tissues (3). Additionally, FPP intake has been recently suggested to improve feed efficiency and the intestinal histological status in broilers (4).

The consumption of certain dietary fibers, including inulin and oligosaccharides, increases the concentrations of intestinal immunoglobulin A (IgA) and mucins, which have roles in the maintenance of gut barrier function $(5,6)$. Colon IgA levels are decreased in patients with ulcerative colitis (7). IgA production was recently suggested to be associated with a decreased incidence of colon cancer (8). The intestinal fermentation of dietary fibers and oligosaccharides is associated with the enhanced intestinal production of $n$-butyrate (9). Elevated intestinal production of $n$-butyrate by fermentation is associated with decreased risks of colon cancer and ulcerative colitis $(10,11)$. Certain fibers and polyphenols are reported to reduce fecal secondary bile acids, such as deoxycholate and lithocholate; secondary bile acids, which are the highly cytotoxic intestinal microbial metabolites of primary bile acid that promote colon cancer development $(12,13)$. A high-fat diet increases fecal secondary bile acids and the production of succinate, a putative pro-inflammatory signal, and decreases $n$-butyrate production (14-16). These alterations are believed to be associated with the increased risks of colon cancer and ulcerative colitis.

Due to the favorable effect of FPP intake on the intestinal histological status in broilers, as mentioned above (4), we hypothesized that FPP intake improves the colonic luminal environment of rats fed a high-fat diet. Therefore, the effects 
of FPP consumption was investigated on intestinal luminal variables, including microflora, fermentation, secondary bile acids, IgA, mucins and harmful enzymes in rats fed a high-fat diet.

\section{Materials and methods}

Materials. The FPP was obtained from Manda Fermentation Co., Ltd., and the chemical composition is shown in Table I.

Animals. Male Sprague-Dawley rats (3-week-old) were purchased from Hiroshima Laboratory Animal Centre (Hiroshima, Japan) and maintained according to the 'Guide for the Care and Use of Laboratory Animals' established by Hiroshima University; the study protocol was approved by the University Ethics Committee. The rats were individually housed in an air-conditioned room at $23-24^{\circ} \mathrm{C}$ with a $12-\mathrm{h}$ light cycle (light, from 08:00 a.m. to 8:00 p.m.). Following acclimatization and feeding with a non-purified commercial rodent diet (moderate fat; Oriental Yeast Co., Ltd., Tokyo, Japan) for 7 days, 13 rats (mean body weight, $105 \mathrm{~g}$ ) were divided into 2 groups with 6 or 7 rats in each. The compositions of the experimental diets are shown in Table II. The FPP was added to the diet at $7.9 \%$ (w/w) $(5 \%$ on dry weight basis). The levels of dietary minerals and fibers in the FPP diet were adjusted by reducing the salt mixture and cellulose, respectively. The amounts of dietary fibers in the FPP were measured using the AOAC 2001.03 enzyme-gravimetric method in combination with high-performance liquid chromatography (17). Equal amounts of each experimental diet were incorporated daily into food cups at 7:00 p.m. $(9,10$, 12,14 and $15 \mathrm{~g}$ for days 1, 2-4, 5-7, 8-13 and 14-21, respectively) to ensure a standardized food intake. All the diet was consumed each day until the diet was served on the following day. The weight of the spilled diet was recorded daily and accounted for in the calculation of food intake. Feces were collected during the last 3 days. At the end of the 21-day feeding period, the rats were sacrificed by decapitation under diethyl ether anaesthesia. The liver, epididymal and perirenal adipose tissues and gastrocnemius muscle were excised rapidly and weighed. The cecum was excised, and its contents were immediately collected, weighed, and stored at $-70^{\circ} \mathrm{C}$ until analysis.

Quantification analyses. Bacterial genomic DNA was extracted from cecal digesta using an Isofecal DNA extraction kit (Nippon Gene, Co., Ltd., Tokyo, Japan) according to the manufacturer's instructions. The cecal microflora was analyzed using a terminal restriction fragment length polymorphism method as described previously (18). Cecal organic acids were measured as described previously (19). Fecal acidic sterols were analyzed using an internal standard (nor-deoxycholic acid; Steraloids, Wilton, NY, USA) by gas chromatography as described previously. The total IgA concentration in feces was measured using an ELISA quantitation kit (Bethyl Laboratories Inc., Montgomery, TX, USA). Mucins were extracted according to the method of Bovee-Oudenhoven et al (20) and quantitated using a fluorometric assay (21). The activities of harmful fecal enzymes, such as tryptophanase, $\beta$-glucuronidase and $\beta$-glucosidase, were determined as described previously (22).
Table I. Chemical composition of FPP.

\begin{tabular}{|c|c|}
\hline Composition per 100 g FPP & FPP \\
\hline Nitrogen x 6.25, g & 2.4 \\
\hline Carbohydrates, g & 55.2 \\
\hline Glucose, $\mathrm{g}$ & 18.6 \\
\hline Fructose, $\mathrm{g}$ & 15.8 \\
\hline Maltose, $\mathrm{g}$ & 0.23 \\
\hline Isomaltose, $\mathrm{g}$ & 0.8 \\
\hline Dietary fibers, $g$ & 3.7 \\
\hline Ash, g & 1.8 \\
\hline $\mathrm{K}, \mathrm{mg}$ & 530 \\
\hline $\mathrm{Ca}, \mathrm{mg}$ & 130 \\
\hline $\mathrm{Mg}, \mathrm{mg}$ & 54 \\
\hline $\mathrm{Na}, \mathrm{mg}$ & 49 \\
\hline $\mathrm{P}, \mathrm{mg}$ & 47 \\
\hline $\mathrm{Fe}, \mathrm{mg}$ & 3.2 \\
\hline $\mathrm{Zn}, \mathrm{mg}$ & 0.6 \\
\hline Water, g & 36.9 \\
\hline Ile, mg & 77 \\
\hline Leu, mg & 142 \\
\hline Lys, mg & 43 \\
\hline Met, mg & 23 \\
\hline Phe, mg & 83 \\
\hline Tyr, mg & 44 \\
\hline Thr, mg & 63 \\
\hline Try, mg & 12 \\
\hline Val, mg & 99 \\
\hline His, mg & 23 \\
\hline $\mathrm{Arg}, \mathrm{mg}$ & 37 \\
\hline Ala, mg & 86 \\
\hline Asp, mg & 238 \\
\hline Glu, mg & 336 \\
\hline Gly, mg & 62 \\
\hline Pro, mg & 115 \\
\hline Ser, mg & 73 \\
\hline Vitamin B1, mg & 0.01 \\
\hline Vitamin B2, mg & 0.02 \\
\hline Vitamin B6, mg & 0.16 \\
\hline Vitamin $\mathrm{K} 1, \mu \mathrm{g}$ & 2 \\
\hline Folic acid, $\mu \mathrm{g}$ & 11.5 \\
\hline Niacin, mg & 0.73 \\
\hline Retinol, $\mu \mathrm{g}$ & 7 \\
\hline$\alpha$-Carotene, $\mu \mathrm{g}$ & 5 \\
\hline$\beta$-Carotene, $\mu \mathrm{g}$ & 85 \\
\hline Soy isoflavone, $\mathrm{mg}$ & 1.3 \\
\hline Total polyphenols, g & 0.48 \\
\hline Lactate, $g$ & 1.2 \\
\hline Acetate, $g$ & 0.3 \\
\hline Tartarate, $\mathrm{g}$ & 0.01 \\
\hline Succinate, $g$ & 0.03 \\
\hline Gluconate, $\mathrm{g}$ & 0.72 \\
\hline
\end{tabular}

FPP, fermented plant product. 
Table II. Composition of the experimental diets.

\begin{tabular}{lrr}
\hline Composition g/100 g & Control & FPP \\
\hline Beef tallow & 30.0 & 30.0 \\
Casein (net protein $17.4 \mathrm{~g} / 100 \mathrm{~g}$ diet) & 20.0 & 19.8 \\
L-cystine & 0.3 & 0.3 \\
Vitamin mixture & 1.0 & 1.0 \\
Salt mixture & 3.5 & 3.4 \\
Cellulose & 5.0 & 4.7 \\
Sucrose & 20.0 & 20.0 \\
Corn starch & 20.2 & 15.8 \\
FPP (net content $5.0 \mathrm{~g} / 100 \mathrm{~g}$ diet) & 0.0 & 7.9 \\
\hline
\end{tabular}

FPP, fermented plant product.

Table III. Body, tissue, cecal content and fecal weights.

\begin{tabular}{llc}
\hline Characteristics & Control & FPP \\
\hline $\begin{array}{l}\text { Final body weight, g } \\
\text { Total food intake, g }\end{array}$ & $253 \pm 4$ & $242 \pm 5$ \\
$\begin{array}{l}\text { Liver weight, g } \\
\text { Epididymal adipose } \\
\text { tissue weight, g }\end{array}$ & $275 \pm 2$ & $271 \pm 5$ \\
$\begin{array}{l}\text { Perirenal adipose } \\
\text { tissue weight, g }\end{array}$ & $3.20 \pm 0.23$ & $3.19 \pm 0.19$ \\
$\begin{array}{l}\text { Gastrocnemius } \\
\text { muscle weight, g }\end{array}$ & $3.85 \pm 0.41$ & $4.06 \pm 0.31$ \\
$\begin{array}{l}\text { Weight of cecum } \\
\text { contents, g }\end{array}$ & $2.86 \pm 0.11$ & $2.59 \pm 0.07$ \\
Fecal dry weight, g/3 days & $3.44 \pm 0.15$ & $3.35 \pm 0.32$ \\
\end{tabular}

Mean \pm standard error $(n=6-7)$. FPP, fermented plant product.

Statistical analysis. Data are expressed as mean \pm standard error. Statistical analysis was performed by Student's t-test. $\mathrm{P}<0.05$ was considered to indicate a statistically significant difference.

\section{Results}

Characteristics. Final body weight, total food intake, weights of tissues and fecal weight did not differ significantly between the groups (Table III). The data of cecal microflora and organic acids are shown in Table IV. The proportions of the cecal microflora examined were unaffected. The cecal level of succinate was markedly reduced in the FPP diet group $(-88 \%$, $\mathrm{P}<0.01)$, while the levels of other organic acids did not differ significantly between groups.

The fecal contents of deoxycholate and hyodeoxycholate acid were significantly lower in the FPP diet group (-50 and $-56 \%$, respectively, $\mathrm{P}<0.05$, Table $\mathrm{V}$ ), while those of cholate and lithocholate were not significantly different. Cecal levels of IgA and mucins were 1.9- and 3.2-fold significantly greater in the FPP diet group ( +91 and $+219 \%$, respectively, $\mathrm{P}<0.05)$. Furthermore, the activity of fecal $\beta$-glucuronidase tended to be lower in the
Table IV. Effect of consumption of fermented plant product (FPP) diet on cecal mucroflora and organic acids.

\begin{tabular}{|c|c|c|c|}
\hline Characteristics & Control & FPP & Change, $\%$ \\
\hline \multicolumn{4}{|l|}{ Cecal microflora, $\%$} \\
\hline Bifidobacterium & $0.74 \pm 0.26$ & $0.40 \pm 0.19$ & \\
\hline Lactobacillales & $16.36 \pm 6.18$ & $10.76 \pm 3.42$ & \\
\hline Bacteroides & $21.60 \pm 4.51$ & $22.76 \pm 4.14$ & \\
\hline Prevotella & $1.99 \pm 0.78$ & $3.67 \pm 1.00$ & \\
\hline $\begin{array}{l}\text { Clostridium } \\
\text { cluster IV }\end{array}$ & $0.52 \pm 0.52$ & $0.29 \pm 0.21$ & \\
\hline $\begin{array}{l}\text { Clostridium } \\
\text { subcluster XIVa }\end{array}$ & $12.50 \pm 1.69$ & $13.90 \pm 1.28$ & \\
\hline $\begin{array}{l}\text { Clostridium } \\
\text { cluster XI }\end{array}$ & $12.39 \pm 1.15$ & $13.60 \pm 1.80$ & \\
\hline $\begin{array}{l}\text { Clostridium } \\
\text { cluster XVIII }\end{array}$ & $4.70 \pm 0.91$ & $3.77 \pm 1.24$ & \\
\hline Others & $29.19 \pm 2.62$ & $30.85 \pm 2.69$ & \\
\hline \multicolumn{4}{|l|}{$\begin{array}{l}\text { Cecal organic acids, } \\
\mu \mathrm{mol} / \text { total contents }\end{array}$} \\
\hline Succinate & $9.3 \pm 2.9$ & $1.1 \pm 0.3^{\mathrm{a}}$ & -88 \\
\hline Lactate & $1.3 \pm 0.3$ & $1.6 \pm 0.2$ & +23 \\
\hline Acetate & $42.7 \pm 3.3$ & $44.6 \pm 6.2$ & +4 \\
\hline Propionate & $15.5 \pm 1.3$ & $13.0 \pm 1.5$ & -16 \\
\hline$n$-Butyrate & $15.9 \pm 2.0$ & $10.7 \pm 2.1$ & -33 \\
\hline Total organic acids & $84.7 \pm 6.8$ & $70.2 \pm 9.7$ & -17 \\
\hline
\end{tabular}

Mean \pm standard error $(n=6-7) .{ }^{a} \mathrm{P}<0.05$ by Student's t-test.

Table V. Effect of dietary FPP on fecal parameters in rats fed a high-fat diet.

Characteristics amount/3 days Control FPP Change, \%

\begin{tabular}{|c|c|c|}
\hline Lithocholate, $\mu \mathrm{mol}$ & $1.00 \pm 0.130 .92 \pm 0.32$ & \\
\hline Deoxycholate, $\mu \mathrm{mol}$ & $1.87 \pm 0.230 .93 \pm 0.26^{\mathrm{a}}$ & -50 \\
\hline Hyodeoxycholate, $\mu \mathrm{mol}$ & $5.78 \pm 0.832 .52 \pm 0.95^{\mathrm{a}}$ & -56 \\
\hline Cholate, $\mu \mathrm{mol}$ & $0.54 \pm 0.200 .18 \pm 0.09$ & \\
\hline $\operatorname{IgA}, \mathrm{mg}$ & $0.89 \pm 0.051 .70 \pm 0.31^{\mathrm{a}}$ & +91 \\
\hline Mucins, mg & $1.18 \pm 0.123 .76 \pm 0.38^{\mathrm{a}}$ & +219 \\
\hline Tryptophanase activity, U & $0.27 \pm 0.060 .90 \pm 0.56$ & \\
\hline$\beta$-glucuronidase activity, $U$ & $3.28 \pm 0.27 \quad 2.51 \pm 0.33$ & \\
\hline$\beta$-glucosidase activity, $\mathrm{U}$ & $0.66 \pm 0.151 .18 \pm 0.31$ & \\
\hline
\end{tabular}

Mean \pm standard error $(\mathrm{n}=6-7) .{ }^{\mathrm{a}} \mathrm{P}<0.05$ by Student's $\mathrm{t}$-test $(\mathrm{P}<0.05)$.

FPP diet group $(-23 \%, \mathrm{P}=0.073)$. The activities of the other enzymes did not differ significantly between the groups.

\section{Discussion}

Notably, the cecal succinate level was markedly reduced by the FPP diet in the present study, whereas other organic acids 
were unaffected. To the best of our knowledge, this is the first evidence of the marked reduction of colonic succinate by dietary factor(s). A high-fat diet was recently found to increase colonic succinate production and decrease butyrate production together with low-grade inflammation (16). Succinate is considered an inflammatory and hypoxic signal; it stabilizes the transcription factor hypoxia-inducible factor- $1 \alpha$ in specific tumors and activated macrophages, and stimulates dendritic cells via succinate receptor GPR91 (23). Succinate, produced abundantly by members of the family Bacteroidaceae, particularly $B$. caccae, is considered the ulcerogenic agent in dextran sulfate sodium colitis (24). Succinic acid has been reported to reduce the proliferation rate of the epithelial cells in the colon, as well as the crypt size (25). Succinic acid has been shown to inhibit the motility of the large intestine and to stimulate water secretion from the small intestine (25). Thus, the present findings raise the possibility that the suppression in cecal succinate by FPP intake is beneficial for the colon. However, further study is required to confirm this.

Another important finding was the marked reduction in fecal deoxycholate and hyodeoxycholate (cytotoxic bile acids) by FPP intake. Deoxycholate is considered cytotoxic to normal colonic crypt cells, resulting in increased compensatory proliferation of colonic epithelium cells, which is associated with an increased risk of colon cancer $(26,27)$. Meanwhile, deoxycholate causes DNA damage and oxidative stress, and has pro-inflammatory activity by activating nuclear factor- $\kappa \mathrm{B}(28)$. Our previous study found that a $0.5 \%$ dietary supplementation with certain polyphenols, particularly curcumin, significantly reduces these secondary bile acids in rats fed a high-fat diet (13). As the FPP diet used in the present study contains a small amount of polyphenols (Table I), it is required to determine whether the effects of the FPP diet are due to the polyphenols in the diet.

The FPP diet significantly increased fecal $\operatorname{Ig} \mathrm{A}$ and mucins, which are responsible for intestinal immune and barrier functions $(5,6)$. Certain dietary fibers and oligosaccharides are reported to increase IgA and mucin levels $(5,6)$. The FPP contains small amounts of dietary fibers (Table I). Therefore, it is required to determine whether these ingredients are responsible for the observed effects. As certain harmful enzymes are considered to be associated with colon cancer $(15,29)$, the activities of such fecal enzymes were examined further. The FPP diet tended to reduce the activity of fecal $\beta$-glucuronidase, although not significantly. Thus, collectively, the FPP diet appeared to be favorable for the luminal environment of rats fed a high-fat diet.

In conclusion, the present study provides evidence that the FPP, Manda Koso, is a beneficial agent for the colonic luminal environment in rats fed a high-fat diet by reducing succinate and deoxycholate levels, and increasing IgA and mucins levels. However, further study is required to elucidate the underlying mechanisms by which the FPP exerts such effects and to identify the active compounds responsible.

\section{References}

1. Shimada T, Motonaga C, Matsuura S, Takagaki M, Ashida T, Okano $\mathrm{T}$ and Morii $\mathrm{H}$ : Effects of a fermented vegetable product on fat deposition and bone metabolism in ovariectomized rats. J Nutr Sci Vitaminol (Tokyo) 50: 422-425, 2004.
2. Ashida T, Okimasu E and Amemura A: Effects of a fermented vegetable product on hemolysis and lipid peroxidation of Japanese flounder erythrocytes. Fish Sci 68: 1324-1329, 2002.

3. Ashida T, Takei Y, Takagaki M, Matsuura Y and Okimatsu E: The dietary effects of a fermented vegetable product on glutathione peroxidase activity and lipid peroxidation of Japanese flounder Paralichthys olivaceus. Fish Sci 72: 179-184, 2006.

4. Lokaewmanee K, Yamauchi K and Thongwittaya N: Effects of fermented plant product on growth performance, some blood variables, carcase characteristics and intestinal histology in broilers. Br Poult Sci 53: 215-223, 2012.

5. Ito H, Wada T, Ohguchi M, Sugiyama K, Kiriyama S and Morita T: The degree of polymerization of inulin-like fructans affects cecal mucin and immunoglobulin A in rats. J Food Sci 73: H36-H41, 2008.

6. Tanabe H, Ito H, Sugiyama K, Kiriyama S and Morita T: Dietary indigestible components exert different regional effects on luminal mucin secretion through their bulk-forming property and fermentability. Biosci Biotechnol Biochem 70: 1188-1194, 2006.

7. Brandtzaeg P, Carlsen HS and Halstensen TS: The B-cell system in inflammatory bowel disease. Adv Exp Med Biol 579: 149-167, 2006.

8. Perdigón G, de Moreno de LeBlanc A, Valdez J and Rachid M: Role of yoghurt in the prevention of colon cancer. Eur J Clin Nutr 56 (Suppl 3): S65-S68, 2002.

9. Nyman M: Fermentation and bulking capacity of indigestible carbohydrates: The case of inulin and oligofructose. Br J Nutr 87 (Suppl 2): S163-S168, 2002

10. Scheppach W: Effects of short chain fatty acids on gut morphology and function. Gut 35 (Suppl 1): S35-S38, 1994.

11. Tang $Y$, Chen Y, Jiang H, Robbins GT and Nie D: G-protein-coupled receptor for short-chain fatty acids suppresses colon cancer. Int J Cancer 128: 847-856, 2011.

12. Reddy B, Engle A, Katsifis S, Simi B, Bartram HP, Perrino P and Mahan C: Biochemical epidemiology of colon cancer: Effect of types of dietary fiber on fecal mutagens, acid and neutral sterols in healthy subjects. Cancer Res 49: 4629-4635, 1989.

13. Han Y, Haraguchi T, Iwanaga S, Tomotake H, Okazaki Y, Mineo S, Moriyama A, Inoue J and Kato N: Consumption of some polyphenols reduces fecal deoxycholic acid and lithocholic acid, the secondary bile acids of risk factors of colon cancer. J Agric Food Chem 57: 8587-8590, 2009.

14. Reddy BS: Dietary fat and its relationship to large bowel cancer. Cancer Res 41: 3700-3705, 1981.

15. Wu WT and Chen HL: Effects of konjac glucomannan on putative risk factors for colon carcinogenesis in rats fed a high-fat diet. J Agric Food Chem 59: 989-994, 2011.

16. Jakobsdottir G, Xu J, Molin G, Ahrné S and Nyman M: High-fat diet reduces the formation of butyrate, but increases succinate, inflammation, liver fat and cholesterol in rats, while dietary fibre counteracts these effects. PLoS One 8: e80476, 2013.

17. Gordon DT and Okuma K: Determination of total dietary fiber in selected foods containing resistant maltodextrin by enzymatic-gravimetric method and liquid chromatography: Collaborative study. J AOAC Int 85: 435-444, 2002.

18. Okazaki Y, Sitanggang NV, Sato S, Ohnishi N, Inoue J, Iguchi T, Watanabe T, Tomotake $\mathrm{H}$, Harada $\mathrm{K}$ and Kato N: Burdock fermented by Aspergillus awamori elevates cecal Bifidobacterium, and reduces fecal deoxycholic acid and adipose tissue weight in rats fed a high-fat diet. Biosci Biotechnol Biochem 77: 53-57, 2013.

19. Okazaki Y, Tomotake H, Tsujimoto K, Sasaki M and Kato N: Consumption of a resistant protein, sericin, elevates fecal immunoglobulin A, mucins and cecal organic acids in rats fed a high-fat diet. J Nutr 141: 1975-1981, 2011.

20. Bovee-Oudenhoven IM, Termont DS, Heidt PJ and Van der Meer R: Increasing the intestinal resistance of rats to the invasive pathogen Salmonella enteritidis: Additive effects of dietary lactulose and calcium. Gut 40: 497-504, 1997.

21. Crowther RS and Wetmore RF: Fluorometric assay of O-linked glycoproteins by reaction with 2-cyanoacetamide. Anal Biochem 163: 170-174, 1987.

22. Lee K, Jang S, Baek EH, Kim MJ, Lee KS, Shin HS, Chung MJ, Kim JE, Lee KO and Ha NJ: Lactic acid bacteria affect serum cholesterol levels, harmful fecal enzyme activity and fecal water content. Lipids Health Dis 8: 21-28, 2009.

23. Mills E and O'Neill LA: Succinate: A metabolic signal in inflammation. Trends Cell Biol 24: 313-320, 2014. 
24. Ariake K, Ohkusa T, Sakurazawa T, Kumagai J, Eishi Y, Hoshi S and Yajima T: Roles of mucosal bacteria and succinic acid in colitis caused by dextran sulfate sodium in mice. J Med Dent Sci 47: 233-241, 2000

25. Inagaki $A$, Ichikawa $H$ and Sakata $T$ : Inhibitory effect of succinic acid on epithelial cell proliferation of colonic mucosa in rats. J Nutr Sci Vitaminol (Tokyo) 53: 377-379, 2007.

26. Bernstein H, Bernstein C, Payne CM, Dvorakova K and Garewal H: Bile acids as carcinogens in human gastrointestinal cancers. Mutat Res 589: 47-65, 2005.

27. Hofmann AF and Hofmann MD: The continuing importance of bile acids in liver and intestinal disease. Arch Intern Med 159: 2647-2658, 1999.
28. Payne CM, Weber C, Crowley-Skillicorn C, Dvorak K, Bernstein H, Bernstein C, Holubec H, Dvorakova B and Garewal H: Deoxycholate induces mitochondrial oxidative stress and activates NF- $\kappa \mathrm{B}$ through multiple mechanisms in HCT-116 colon epithelial cells. Carcinogenesis 28: 215-222, 2007.

29. Kim DH and Jin YH: Intestinal bacterial $\beta$-glucuronidase activity of patients with colon cancer. Arch Pharm Res 24: 564-567, 2001. 